\title{
Anti-influenza viral effects of novel nuclear export inhibitors from Valerianae Radix and Alpinia galanga
}

\author{
Ken Watanabe ${ }^{1}$, Hanae Takatsuki ${ }^{1}$, Megumi Sonoda $^{1}$, Satoru Tamura ${ }^{2}$, Nobutoshi Murakami ${ }^{2}$, \\ Nobuyuki Kobayashi ${ }^{1,3, *}$ \\ ${ }^{1}$ Laboratory of Molecular Biology of Infectious Agents, Graduate School of Biomedical Sciences, Nagasaki University, Nagasaki, \\ Japan; \\ ${ }^{2}$ Laboratory of Exploration of Medicinal Plant Resources, Graduate School of Pharmaceutical Sciences, Osaka University, Osaka, \\ Japan; \\ ${ }^{3}$ Central Research Center, AVSS Corporation, Nagasaki, Japan.
}

\begin{abstract}
Many pathogenic viruses, such as the influenza virus and the Human Immunodeficiency Virus (HIV)-1, are a threat to humans, thus leading to thousands of deaths annually. The development of antiviral drugs is urgent, and it is an essential strategy for the suppression of these infectious diseases. However, regardless of the rapid emergence of many infectious diseases, the development of novel antiviral drugs has been slow, except for the case of the AIDS. In addition, several viruses can easily mutate and escape the inhibitory activity of anti-viral drugs. It was already well-established that HIV escapes from anti-viral drug effects because of the lack of proofreading activity in its reverse transcriptase. It is known that the influenza virus, which is resistant to Tamiflu, is already spread all over the world. Viruses utilize the host cell environment and cellular factors to propagate. Therefore, the development of novel drugs which inhibit viral protein-host protein interactions or cellular functions appear to be good candidates. The influenza virus is unique in replicating in host nuclei, and we therefore focused on the nuclear export processes for the development of anti-influenza viral drugs. We previously reported that leptomycin B (LMB), which inhibited the nuclear export processes via the nuclear export signal (NES) inhibited the nuclear export of influenza viral RNP (vRNP), and resulted in the inhibition of influenza viral propagation. We herein examined novel CRM1 inhibitors, valtrate from Valerianae Radix, and 1'-acetoxychavicol acetate (ACA) from Alpinia galanga as potent inhibitors for the influenza virus replication.
\end{abstract}

\footnotetext{
*Address correspondence to:

Dr. Nobuyuki Kobayashi, Laboratory of Molecular Biology of Infectious Agents, Graduate School of Biomedical Sciences, Nagasaki University, 1-14 Bunkyo-machi, Nagasaki 852-8521, Japan.

e-mail:nobnob@nagasaki-u.ac.jp
}

Keywords: 1'-acetoxylchavicol acetate, valtrate, influenza virus, nuclear export, antiviral

\section{Introduction}

Nuclear pore complexes (NPCs) mediate the bidirectional transport of molecules between the cytoplasm and the nucleus. The NPC forms a channel that is approximately $9 \mathrm{~nm}$ in diameter. Small molecules with a molecular mass of less than $40 \mathrm{kDa}$ can diffuse through this channel. However, larger molecules are transported through this channel by energy-dependent mechanisms. In the nuclear import processes, the proteins that are selectively transported to the nucleus have a sequence called the nuclear localization signal (NLS). The cellular factor importin-alpha, which complexes with importinbeta, binds to the NLS and passes through the NPC into the nucleus (1). In the nuclear export processes, proteins are selectively exported from the nucleus to the cytoplasm when they contain a leucine-rich consensus sequence called the nuclear export signal (NES) (2). The NES binds to the nuclear export factor CRM1, and nuclear export occurs under the regulation of the Ran protein (3); for a review, see (4). The NES was identified in various proteins such as HIV-1 Rev (5), protein kinase A inhibitor (2), MKK6 (an activator of p38 MAPK) (6), p53 (7).

The influenza virus binds to sialic acids on the cell surface through hemagglutinin (HA) and it is incorporated into the cell via endocytosis. The viral ribonucleoprotein complex (vRNP) is released into the cytoplasm by M2 protein ion channel activity. In contrast to many other RNA viruses, replication of the influenza virus occurs in the nucleus (8). The vRNP consists of viral RNA, NP and the viral RNA polymerases PA, PB1, and PB2, and each vRNP protein contains an NLS. Therefore, the viral RNP is transported into the nucleus by the NLS-mediated nuclear import pathway. In the 
nucleus, early transcription from vRNP occurs and viral mRNAs are exported from the nucleus. Newlysynthesized viral early proteins NP, PB1, PB2, and PA are imported into the nucleus via their NLS, and complex with newly-synthesized viral RNA. The late transcription occurs from progeny vRNP, and the viral late proteins M1, M2, HA, NA, and NS2 are synthesized thereafter. It has been reported that M1 and NS2 are important for the nuclear export of the progeny vRNP. M1 binds to both vRNP and NS2, but only NS2 have an NES. However the function of M1 for the nuclear export of vRNP is not yet completely understood, since M1 does not contain an NES. The nuclear export of vRNP is hypothesized to be mediated as the vRNP-M1-NS2-CRM1 complex $(9,10)$. However, other reports have suggested that NS2 is not essential for the nuclear export of vRNP, since NS2 does not colocalize with RNP (11). Recently, we have identified that the host heat shock protein Hsc70 can bind to M1 and mediates the nuclear export of vRNP $(12,13)$. Hsc70 has an NES signal (14) and processes the nuclear export of importin and transportin (15). Therefore, either NS2, Hsc70, or both may mediate the nuclear export of vRNP. These findings suggest that the inhibition of the influenza viral RNP nuclear export by a specific nuclear export inhibitor is effective for reducing the influenza virus production (13).

Antiviral drugs are one of the most important strategies for the treatment of infected patients, but some viruses, especially RNA viruses, easily mutate and become resistant to drugs designed for viral gene products. It is well known that the influenza virus, which is resistant to amantadine (the inhibition of viral M2 protein) or Tamiflu (a viral neuraminidase inhibitor), is already spreading throughout the world. The same problems are prevalent in HIV treatment, and a recent multi-drug combination therapy protocol, termed HAART therapy, is essential to treat patients with HIV. Novel drugs that target cellular proteins may avoid such problems. Inhibitors that regulate the nuclear export system appear to be a good candidate for HIV therapy. We recently demonstrated that leptomycin B (LMB) treatment inhibits the nuclear export of influenza viral vRNP and results in reduced viral production (13). However, LMB and its derivatives are highly hydrophobic, and are therefore unsuitable for clinical treatment purposes. Previously we reported a new class of nuclear export inhibitors, valtrate and 1'-acetoxychavicol acetate (ACA) (Figure 1) which were isolated from Valerianae Radix, the roots of Valeriana fauriei (16) and the roots of Alpinia galanga (17), respectively. These compounds covalently bind to the CRM1, and inhibit the nuclear export of HIV-1 Rev containing NES (16,17). Since valtrate and ACA possess moderate hydrophobicity which is suitable for chemotherapeutic application, we herein examined whether valtrate and ACA can inhibit the nuclear export of influenza viral RNP complex and reduce viral production.

\section{Materials and Methods}

\subsection{Cells, virus, chemicals and antibody}

Madin-Darby canine kidney (MDCK) cells were grown in Eagle's Minimum Essential Medium (MEM) supplemented with $5 \%$ fetal bovine serum (FBS) at $37^{\circ} \mathrm{C}$ in $5 \% \mathrm{CO}_{2}$. HeLa cells were grown in MEM supplemented with $10 \% \mathrm{FBS}$ at $37^{\circ} \mathrm{C}$ in $5 \% \mathrm{CO}_{2}$. Influenza virus A/WSN/33(H1N1) was propagated in 10-day-old embryonated eggs as described previously (12) and titrated by the plaque assay as described below. LMB was purchased from Enzo Life Sciences International, Inc. (PA, USA) and was dissolved in EtOH at a concentration of $10 \mu \mathrm{g} / \mathrm{mL}$. The solution was stored at $-20^{\circ} \mathrm{C}$. ClogPs of valtrate, ACA, and LMB were calculated using the computer software program (version 4.0, Bio Byte Corporation, CA, USA). An anti-NP mouse mAb that specifically binds to vRNP was kindly supplied by Dr. Fumitaka Momose (Kitazato University) (18).

\subsection{Isolation of valtrate and ACA}

Isolation of valtrate: The crushed Valerianae Radix (100 g, Tochimoto Tenkaido, Osaka, Japan) was extracted with $\mathrm{MeOH}$ at room temperature for $6 \mathrm{~h}$. After filtration, the residue was further extracted with $\mathrm{MeOH}$ under reflux for $3 \mathrm{~h}$ twice. The combined filtrates were concentrated under reduced pressure to give $\mathrm{MeOH}$ extract (13.2 g). The extract was partitioned between EtOAc and $\mathrm{H}_{2} \mathrm{O}$, and the EtOAc layer was evaporated in vacuo to yield the EtOAc extract $(3.6 \mathrm{~g})$. The extract was separated by $\mathrm{SiO}_{2}$ column chromatography ( $80 \mathrm{~g}$ ) using $n$-hexane-EtOAc $(20: 1 \rightarrow 5: 1 \rightarrow 1: 1)$ as eluents to provide the fraction (97.2 $\mathrm{mg}$ ) containing valtrate. The fraction was further separated by normal-phase HPLC [column: Cosmosil 5SL $10 \times 250 \mathrm{~mm}$ (Nacalai Tesque, Kyoto, Japan), flow rate: $4.0 \mathrm{~mL}$, mobile phase: $n$-hexane:EtOAc $=$ 10:1, detection: $220 \mathrm{~nm}$ ] to give a crude mixture of valtrate. The mixture was finally purified by reversephase HPLC [column: Cosmosil 5C18-AR-II $10 \times 250$ mm (Nacalai Tesque, Kyoto, Japan), flow rate: $3.0 \mathrm{~mL}$, mobile phase: $\mathrm{MeOH}: \mathrm{H}_{2} \mathrm{O}=4: 1$, detection: $220 \mathrm{~nm}$ ] to furnish valtrate $(6.3 \mathrm{mg})(16)$. After the purified valtrate was dissolved in DMSO at a concentration of $5 \mathrm{mg} / \mathrm{mL}$, the solution was stored at $-20^{\circ} \mathrm{C}$.

Isolation of ACA: The dried and powdered roots of A. galanga (22 g, Shinwa Bussan, Osaka, Japan) were extracted with $\mathrm{MeOH}$ in the same manner in the extraction of the crushed Valerianae Radix. The combined filtrates were concentrated under reduced pressure to give $\mathrm{MeOH}$ extract $(2.1 \mathrm{~g})$. The extract (210 $\mathrm{mg}$ ) was separated by $\mathrm{SiO}_{2}$ (Fuji Silysia Chemical, Kasugai, Japan) column chromatography (6 g) using $n$-hexane-EtOAc $(20: 1 \rightarrow 10: 1 \rightarrow 1: 1)$ as eluents to 
furnish 1'-acetoxychavicol acetate (31.7 mg, ACA) (17). After the purified ACA was dissolved in DMSO at a concentration of $10 \mathrm{mg} / \mathrm{mL}$, the solution was stored at $-20^{\circ} \mathrm{C}$.

\subsection{Preparation of inhibitor solutions and virus suspensions}

The inhibitor solutions were prepared from the stock solutions of valtrate, ACA, and LMB by dilution to the indicated concentrations with the culture media just prior to use. In the experiment of nuclear translocation assay, the solutions were diluted with the culture medium. The concentrations of DMSO and EtOH in the culture media were $0.5 \%$ and $0.1 \%$, respectively. The virus suspensions were prepared from the titrated virus sample by dilution to the indicated multiplicity of infection (MOI) with 1\% BSA in MEM just prior to use.

\subsection{Indirect immunofluorescence}

HeLa cells were seeded onto a 12 -well plate at a concentration of $5 \times 10^{4}$ cells per well with $1 \mathrm{~mL}$ of MEM containing 10\% FBS and were incubated for $15 \mathrm{~h}$. After washing with MEM twice, the cells were infected with $200 \mu \mathrm{L}$ of the influenza virus suspension at a MOI of 3 at $37^{\circ} \mathrm{C}$ in $5 \% \mathrm{CO}_{2}$ for $1 \mathrm{~h}$. After the medium was removed, the cells were further incubated with $0.5 \mathrm{~mL}$ of the inhibitor solutions for $9 \mathrm{~h}$. The cells were fixed with $4 \%$ paraformaldehyde in PBS for $10 \mathrm{~min}$ and were treated with a wash buffer $(0.1 \% \mathrm{NP}-40$ in PBS) for $20 \mathrm{~min}$. The cells were immersed in a blocking solution (1\% skim milk in PBS) for $1 \mathrm{~h}$, and then were treated with anti-NP mouse $\mathrm{mAb}$ in the blocking solution for $1 \mathrm{~h}$. After rinsing with the wash buffer for three times, the cells were further treated with Alexa 546-conjugated anti-mouse immunoglobulin (Ig) in the blocking solution for $1 \mathrm{~h}$. The cells were washed with the wash buffer, and then location of NP was observed with a fluorescence microscopy (Axiophot, Carl Zeiss, Germany).

\subsection{Evaluation of anti-influenza viral effects}

MDCK cells were seeded onto a 96-well plate at a concentration of $3 \times 10^{4}$ cells per well with $0.1 \mathrm{~mL}$ of MEM containing 5\% FBS and were incubated for $15 \mathrm{~h}$. After washing with MEM twice, the cells were infected with $100 \mu \mathrm{L}$ of the influenza virus suspension at a $\mathrm{MOI}$ of 0.01 at $37^{\circ} \mathrm{C}$ in $5 \% \mathrm{CO}_{2}$ for 1 $\mathrm{h}$. The medium was removed, and then the cells were incubated with $200 \mu \mathrm{L}$ of the inhibitor solutions. After $12 \mathrm{~h}$ or $24 \mathrm{~h}$, an aliquot $(5 \mu \mathrm{L})$ of each supernatant was appropriately diluted and the resulting samples were subjected to the plaque assay to evaluate antiinfluenza viral effects.

\subsection{Plaque assay}

MDCK cells were seeded onto a 6 -well plate at a concentration of $2 \times 10^{6}$ cells per well with $2 \mathrm{~mL}$ of MEM containing 5\% FBS and were incubated for 15 h. The medium was removed, and then the cells were infected with $400 \mu \mathrm{L}$ of virus suspension at $37^{\circ} \mathrm{C}$ in $5 \%$ $\mathrm{CO}_{2}$ for $1 \mathrm{~h}$. After the medium was removed, the cells were overlaid with $4 \mathrm{~mL}$ of agarose solution [MEM containing $0.8 \%$ agarose, $0.1 \% \mathrm{BSA}$ and $1 \% 100$ $\times$ Vitamin solution (Lifetechnologies Japan, Tokyo, Japan)] and were incubated for 3 days. To visualize the plaques, the cells were fixed in AcOH:EtOH (1:1) for $1 \mathrm{~h}$, and then were stained with $0.5 \%$ Amido black 10B solution (Nacalai Tesque) for $3 \mathrm{~h}$. After washing with water and air-drying, the number of plaques was visibly counted. The viral titer was determined as PFU (plaque forming unit) $/ \mathrm{mL}$.

\subsection{Determination of $C C_{50}$ and $I C_{50}$ values of $v R N P$ - export inhibitors}

MDCK cells were seeded onto a 96-well plate at a concentration of $3 \times 10^{4}$ cells per well with $0.1 \mathrm{~mL}$ of MEM containing 5\% FBS and were incubated for 15 h. In the case of the determination of $\mathrm{CC}_{50}$ values $(50 \%$ cell toxicity concentrations of samples), the medium was removed, and then the cells were incubated with $200 \mu \mathrm{L}$ of the inhibitor solutions for $12 \mathrm{~h}$. After the medium was removed, the cells were treated with $0.5 \%$ crystal violet in $70 \% \mathrm{EtOH}$ for $5 \mathrm{~min}$. After washing with water and air-drying, the absorbance was measured at $560 \mathrm{~nm}$ with an Infinite M200 Tecan plate reader (Wako Pure Chemical Industries, Osaka, Japan) to evaluate cell toxicity. In the case of the determination of $\mathrm{IC}_{50}$ values, $(50 \%$ virus inhibitory concentrations of samples), successive viral infection and inhibitor treatment for $12 \mathrm{~h}$ were conducted in the same manner in the experiment of evaluation of antiinfluenza viral effects. After an aliquot $(5 \mu \mathrm{L})$ of each supernatant was appropriately diluted, the resulting samples were subjected to the plaque assay to evaluate anti-influenza viral effects. The $\mathrm{CC}_{50}$ and the $\mathrm{IC}_{50}$ values were calculated from the dose-response curves using the Graph Pad Prism software program (Prism version 5.01, Graph Pad Software, Inc., CA, USA).

\section{Results}

\subsection{Valtrate and ACA inhibit the nuclear export of $v R N P$}

We established a cell line that stably expressed the GFP protein conjugated with an NES signal (GES5 cells) (19). The GES5 cells were treated with a series of inhibitors (Figure 1) for $9 \mathrm{~h}$, and the nuclear 


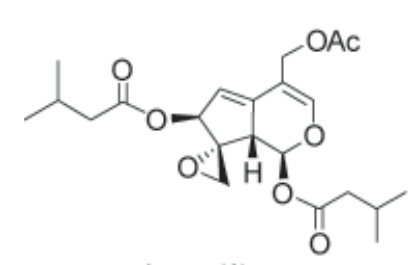

valtrate (1)<smiles>CC(=O)Oc1ccc(-c2ccc(C)o2)cc1</smiles>

$\mathrm{ACA}(2)$

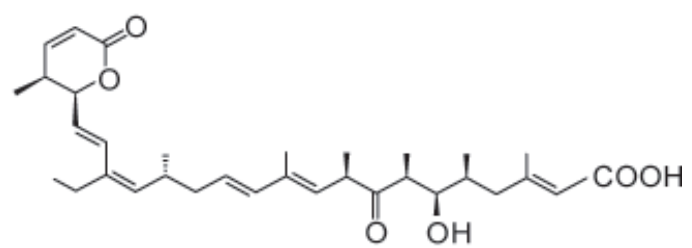

LMB (3)

Figure 1. Chemical structures of valtrate (1), ACA (2), and LMB (3).

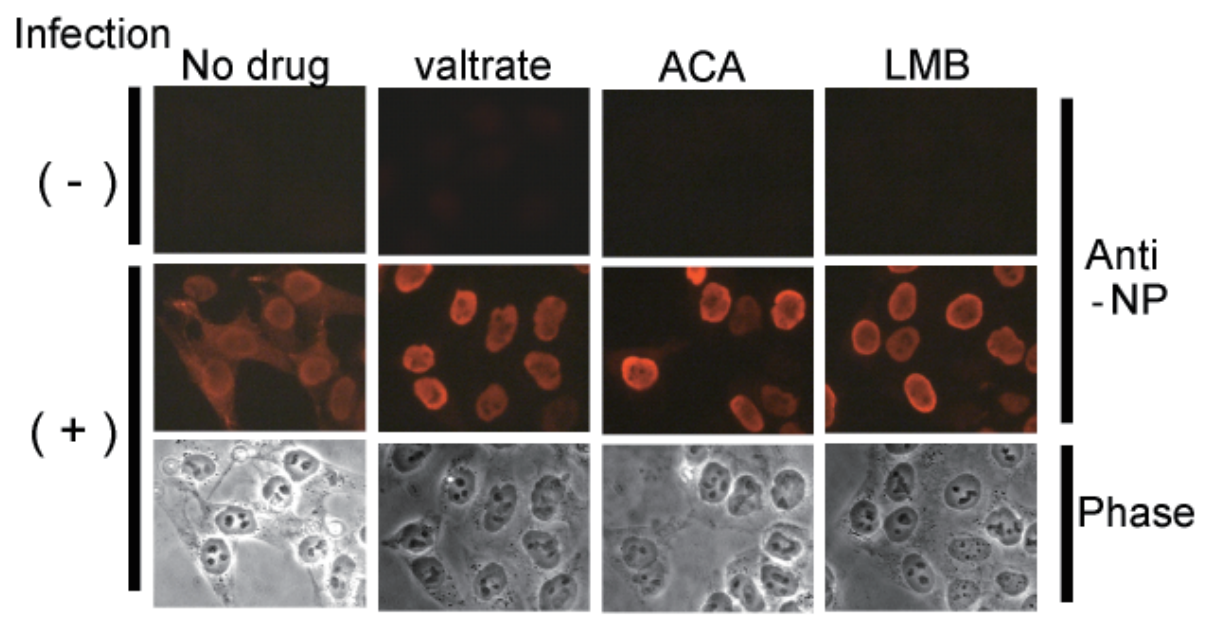

Figure 2. Effect of vRNP-export inhibitors on the nuclear accumulation of influenza viral NP. HeLa cells infected with the influenza virus A/WSN/33 strain were incubated with valtrate $(1.5 \mu \mathrm{g} / \mathrm{mL}, 3.6 \mu \mathrm{M})$, ACA $(3 \mu \mathrm{g} / \mathrm{mL}, 12.8 \mu \mathrm{M})$, or LMB $(10 \mathrm{ng} / \mathrm{mL}$, $18.5 \mathrm{nM}$ ) for $9 \mathrm{~h}$. The influenza viral NP was detected by an indirect immunofluorescence technique. The localization of NP and the location of cells was respectively observed as fluorescence (anti-NP) and phase contrast (phase) with the fluorescence microscopy.

localization of GFP-NES was observed with the fluorescence microscopy. The minimum inhibitory concentrations (MIC) of valtrate, ACA, and LMB were $1 \mu \mathrm{g} / \mathrm{mL}(2.4 \mu \mathrm{M}), 3 \mu \mathrm{g} / \mathrm{mL}(12.8 \mu \mathrm{M})$, and 0.3 $\mathrm{ng} / \mathrm{mL}(0.6 \mathrm{nM})$, respectively (data not shown). To monitor whether valtrate and ACA can inhibit the nuclear export of vRNP, indirect immunofluorescence experiment was performed (Figure 2). HeLa cells were infected with the influenza virus for $1 \mathrm{~h}$. Nuclear export inhibitors were added into the culture plate then incubated for another $9 \mathrm{~h}$. After fixation, the cells were incubated with an anti-NP mAb. NP is a viral protein and is one of the major components of the vRNP. The mAb used in the current study was developed by Momose et al. (18) and recognizes the conformational epitope of the NP; therefore, it preferentially interacts with the vRNP complex rather than the NP alone. In the influenza virusinfected cells, NP localized in the nucleus and in the cytoplasm, and its accumulation in the nucleus was not observed. However, in the presence of LMB, NP drastically accumulated in the nucleus, as has been previously reported (20), since viral NS2 or host factor Hsc70 which possesses an NES is known to associate with vRNP. When the cells were treated with valtrate or ACA, the nuclear accumulation of NP was also clearly observed. These results show that valtrate and ACA efficiently suppress the nuclear export of influenza viral vRNP.

\subsection{Valtrate and ACA suppress the influenza virus production}

To determine whether valtrate and ACA affect influenza virus production, MDCK cells were firstly infected with the influenza virus $\mathrm{A} / \mathrm{WSN} / 33$ for $1 \mathrm{~h}$, then valtrate or ACA were added into the plate (Figure 3). At 12 or 24 $\mathrm{h}$ after viral infection, the supernatants of the infected cells were recovered and subjected to a plaque assay. In the absence of vRNP-export inhibitors, the viral titer in the supernatant were not significantly differed at 12 and $24 \mathrm{~h}$. However, we observed that the viral titer in the supernatant of cells treated with valtrate $\left(<10^{2} \mathrm{PFU} / \mathrm{mL}\right)$, ACA $\left(4 \times 10^{2} \mathrm{PFU} / \mathrm{mL}\right)$, and LMB $\left(<10^{2} \mathrm{PFU} / \mathrm{mL}\right)$, was markedly reduced at $12 \mathrm{~h}$. Twenty-four hours after infection, similar results with the 12-h samples were obtained, except the ACA treated cells.

The $\mathrm{CC}_{50}$ value of the vRNP-export inhibitors were calculated by crystal violet staining method (Table 1). The $\mathrm{CC}_{50}$ value of valtrate was $36 \mu \mathrm{M}(15 \mu \mathrm{g} / \mathrm{mL})$, and the $\mathrm{CC}_{50}$ of ACA was $5.5 \mu \mathrm{M}(1.3 \mu \mathrm{g} / \mathrm{mL})$. Cytotoxicity, as evaluated by the WST-1 assay, gave similar results (data not shown). The $\mathrm{IC}_{50}$ was calculated by titrating the viruses in the cell culture supernatant using the plaque assay (Table 1). The $\mathrm{IC}_{50}$ of valtrate was $0.19 \mu \mathrm{M}$ (82 ng/mL), and the $\mathrm{IC}_{50}$ of ACA was $2.0 \mu \mathrm{M}$ (460 ng/ $\mathrm{mL})$. The selective index of valtrate and ACA was found to be 180 and 2.8, respectively. The selective index of LMB was calculated to be greater than 16,000 . 


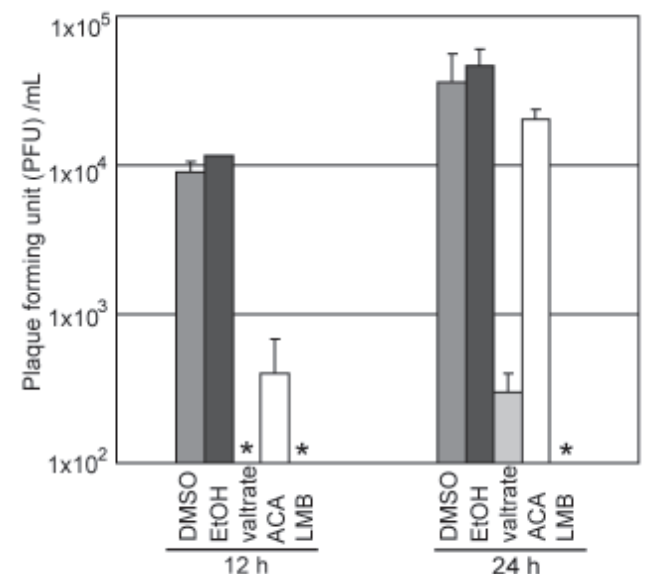

Figure 3. Nuclear vRNP-export inhibitors suppress the influenza viral production. MDCK cells infected with the influenza virus $\mathrm{A} / \mathrm{WSN} / 33$ strain were treated with valtrate $(1.5 \mu \mathrm{g} / \mathrm{mL}, 3.6 \mu \mathrm{M})$, ACA $(1.5 \mu \mathrm{g} / \mathrm{mL}, 6.4 \mu \mathrm{M})$, or LMB $(15$ $\mathrm{ng} / \mathrm{mL}, 27.8 \mathrm{nM})$. After 12 or $24 \mathrm{~h}$, the anti-influenza viral effects were evaluated by the plaque assay. Samples treated with $0.5 \%$ DMSO and $0.1 \%$ EtOH were used as the vehicle controls. Asterisks indicate below the detection limit $\left(<10^{2}\right.$ PFU $/ \mathrm{mL}$ ). The results are represented by the mean \pm S.D. obtained from the three independent experiments.

Table 1. Anti-influenza viral effects of nuclear export inhibitors of $\mathrm{VRNP}^{\mathrm{a}}$

\begin{tabular}{|c|c|c|c|}
\hline Compound & $\mathrm{CC}_{50}(\mu \mathrm{M})^{\mathrm{b}}$ & $\mathrm{IC}_{50}(\mu \mathrm{M})^{\mathrm{c}}$ & Selective index (SI) \\
\hline valtrate & 36 & 0.19 & 180 \\
\hline ACA & 5.5 & 2.0 & 2.8 \\
\hline leptomycin B & $>1.9$ & 0.00012 & $>16,000$ \\
\hline
\end{tabular}

${ }^{\mathrm{a}}$ Evaluation after $12 \mathrm{~h}$ treatment.

b $50 \%$ Cytotoxic concentration.

$50 \%$ Virus growth inhibitory concentration.

${ }^{\mathrm{d}}$ Selective index $=\mathrm{CC}_{50} / \mathrm{IC}_{50}$

\section{Discussion}

The present study demonstrated that a new class of nuclear export inhibitors, valtrate and ACA, regulates the nuclear export of influenza viral RNP (Figure 2) and effectively suppresses virus production (Figure $3)$. The transcription and replication of the influenza virus occurs in the nucleus, and the nuclear import and the export of vRNP are important steps in the viral life cycle. We previously reported that the nuclear export of vRNP occurs from 6 to $9 \mathrm{~h}$ after viral infection (20) and then viral production occurs approximately $12 \mathrm{~h}$ after infection (12). Accumulated vRNP in the nucleus was observed at $9 \mathrm{~h}$ after infection when valtrate or ACA was present in the culture medium (Figure 2). These results suggest that the vRNP-export inhibitors are effective during the influenza virus life cycle.

LMB has been reported to inhibit the CRM1mediated nuclear export system by binding to the Cys529 residue of CRM1 (21). Using a biotinylated LMB as a probe, competition experiments using valtrate or ACA showed that the addition of valtrate and ACA competed with the binding of LMB to CRM1. Therefore, valtrate or ACA inhibition of nuclear export appeared to act through a similar mechanism as $\operatorname{LMB}(16,17)$. We also reported that influenza virus production is significantly decreased in the presence of LMB (13). The selective index of LMB (12 h treatment) is good compared to that of valtrate and ACA (Table 1). However, our preliminary results show that longer time treatment of LMB show significant cytotoxicity to the cells $\left[\mathrm{CC}_{50}: 110 \mathrm{ng} / \mathrm{mL}\right.$ $(200 \mathrm{nM})$ at $48 \mathrm{~h}, 11 \mathrm{ng} / \mathrm{mL}(20 \mathrm{nM})$ at $72 \mathrm{~h}$ in MDCK cells]. It was previously reported that LMB treatment for $72 \mathrm{~h}$ resulted in the formation of polynuclear giant cells (22). Therefore, prolonged treatment with LMB is strongly toxic to cells. The cytotoxicity of valtrate and ACA (valtrate: $4,000 \mathrm{ng} / \mathrm{mL}(9.5 \mu \mathrm{M})$ at $48 \mathrm{~h}$ and 4,100 $\mathrm{ng} / \mathrm{mL}(9.8 \mu \mathrm{M})$ at $72 \mathrm{~h}$; ACA: $780 \mathrm{ng} / \mathrm{mL}(3.3 \mu \mathrm{M})$ at $48 \mathrm{~h}, 850 \mathrm{ng} / \mathrm{mL}(3.6 \mu \mathrm{M})$ and at $72 \mathrm{~h}$, respectively) was not drastically altered. $\mathrm{C} \log \mathrm{P}$ is a parameter correlated to the permeability of drugs, and is therefore believed to be an important index in predicting the biological activity in animal models. Generally, clogP values larger than +3 and less than -3 tend to significantly lose the in vivo pharmacological efficacy, regardless of a good in vitro biological score (23). The hydrophobicity of LMB is very high $(\operatorname{cog} \mathrm{P}=+6.9)$, and therefore the application of LMB is not yet established. In contrast to LMB, valtrate $(\operatorname{cog} \mathrm{P}=+1.92)$ and $\mathrm{ACA}(\operatorname{cog} \mathrm{P}=+1.86)$ have moderate hydrophobicity, and therefore may be clinically applicable. Valtrate and ACA are isolated from medicinal plants Valerianae Radix and A. galanga, respectively. The former has been orally administered as a traditional folk medicine in Japan and China, and the latter has been used as a spice or ginger substitute for flavoring foods in the Southeast Asia and as a traditional folk medicine by oral administration in China and Thailand. Considering the safety of these traditional uses, valtrate and ACA are suitable as lead compounds for further development of inhibitors for nuclear export of vRNP.

The anti-influenza drugs clinically available are directed against viral proteins. Amantadine blocks the ion-channel activity of the viral M2 protein, which is required for viral entry and is effective only for the type A influenza virus. Zanamivir and oseltamivir block the receptor-destroying activity of the viral NA protein, prevent viral budding form the cell surface and are effective against type A and type B influenza viruses. Currently, these drugs are approved and commercially available in many countries. However, the influenza virus easily changes its genomic sequence, and many mutated drug-resistant viruses have been already reported; for a review, see (24). It is essential to develop novel antiinfluenza virus drugs, especially agents that are effective against resistant viruses. It has been reported that the nuclear export of vRNP is mediated by the viral proteins M1 and NS2 $(9,25)$, and is inhibited by LMB treatment $(11,26)$. The nuclear export of vRNP is also mediated by the cellular protein CRM1. Therefore, inhibitors that affect this nuclear export system could be used as antiinfluenza agent. It has been reported that the replication 
of other viruses, such as HIV-1 and HSV-1, are also inhibited by treatment with nuclear export inhibitors $(16,27)$. Specific cellular proteins essential for viral propagation, such as CRM1, may therefore be a good target for the development of novel drugs which can suppress many viral diseases, including the influenza virus, without inducing viral resistance.

\section{Acknowledgements}

This work was partly supported by a Grant-in-Aid for Ministry of Education, Culture, Sports, Science and Technology and by a Grant-in-Aid for Scientific Research from Nagasaki University, Japan (K.W.) and by a global COE program of Nagasaki University, MEXT, Japan (N.K).

\section{References}

1. Adam SA, Gerace L. Cytosolic proteins that specifically bind nuclear location signals are receptors for nuclear import. Cell. 1991; 66:837-847.

2. Wen W, Meinkoth JL, Tsien RY, Taylor SS. Identification of a signal for rapid export of proteins from the nucleus. Cell. 1995; 82:463-473.

3. Fornerod M, Ohno M, Yoshida M, Mattaj IW. CRM1 is an export receptor for leucine-rich nuclear export signals. Cell. 1997; 90:1051-1060

4. Nagata K, Takizawa N, Haruki H, Mibayashi M, Watanabe K. Nuclear import and export of influenza virus ribonucleoprotein complexes. In: Recent advances in influenza virus research (Hayase Y, ed.). Research Signpost, Kerala, India, 2002; pp. 14-43.

5. Fischer U, Huber J, Boelens WC, Mattaj IW, Luhrmann R. The HIV-1 Rev activation domain is a nuclear export signal that accesses an export pathway used by specific cellular RNAs. Cell. 1995; 82:475-483.

6. Hashimoto H, Fukuda M, Matsuo Y, Yokoyama Y, Nishida E, Toyohara H, Sakaguchi M. Identification of a nuclear export signal in MKK6, an activator of the carp p38 mitogen-activated protein kinases. Eur J Biochem. 2000; 267:4362-4371.

7. Stommel JM, Marchenko ND, Jimenez GS, Moll UM, Hope TJ, Wahl GM. A leucine-rich nuclear export signal in the 553 tetramerization domain: Regulation of subcellular localization and p53 activity by NES masking. Embo J. 1999; 18:1660-1672.

8. Herz C, Stavnezer E, Krug R, Gurney T Jr. Influenza virus, an RNA virus, synthesizes its messenger RNA in the nucleus of infected cells. Cell. 1981; 26:391-400.

9. O'Neill RE, Talon J, Palese P. The influenza virus NEP (NS2 protein) mediates the nuclear export of viral ribonucleoproteins. Embo J. 1998; 17:288-296.

10. Neumann G, Hughes MT, Kawaoka Y. Influenza A virus NS2 protein mediates vRNP nuclear export through NESindependent interaction with hCRM1. Embo J. 2000; 19:6751-6758.

11. Ma K, Roy AM, Whittaker GR. Nuclear export of influenza virus ribonucleoproteins: Identification of an export intermediate at the nuclear periphery. Virology. 2001; 282:215-220.

12. Watanabe K, Fuse T, Asano I, Tsukahara F, Maru Y, Nagata
K, Kitazato K, Kobayashi N. Identification of Hsc70 as an influenza virus matrix protein (M1) binding factor involved in the virus life cycle. FEBS Lett. 2006; 580:5785-5790.

13. Watanabe K, Takizawa N, Noda S, Tsukahara F, Maru Y, Kobayashi N. Hsc70 regulates the nuclear export but not the import of influenza viral RNP: A possible target for the development of anti-influenza virus drugs. Drug Discov Ther. 2008; 2:77-84.

14. Tsukahara F, Maru Y. Identification of novel nuclear export and nuclear localization-related signals in human heat shock cognate protein 70. J Biol Chem. 2004; 279:8867-8872.

15. Kose S, Furuta M, Koike M, Yoneda Y, Imamoto N. The $70-\mathrm{kD}$ heat shock cognate protein (hsc70) facilitates the nuclear export of the import receptors. J Cell Biol. 2005; 171:19-25.

16. Murakami N, Ye Y, Kawanishi M, Aoki S, Kudo N, Yoshida M, Nakayama EE, Shioda T, Kobayashi M. New Rev-transport inhibitor with anti-HIV activity from Valerianae Radix. Bioorg Med Chem Lett. 2002; 12:2807-2810.

17. Tamura S, Shiomi A, Kaneko M, Ye Y, Yoshida M, Yoshikawa M, Kimura T, Kobayashi M, Murakami N. New Rev-export inhibitor from Alpinia galanga and structure-activity relationship. Bioorg Med Chem Lett. 2009; 19:2555-2557.

18. Momose F, Kikuchi Y, Komase K, Morikawa Y. Visualization of microtubule-mediated transport of influenza viral progeny ribonucleoprotein. Microbes Infect. 2007; 9:1422-1433.

19. Watanabe K, Noda S, Kobayashi N. Establishment of a new cell line for performing sensitive screening of nuclear export inhibitors. Drug Discov Ther. 2008; 2:7-9.

20. Watanabe K, Takizawa N, Katoh M, Hoshida K, Kobayashi N, Nagata K. Inhibition of nuclear export of ribonucleoprotein complexes of influenza virus by leptomycin B. Virus Res. 2001; 77:31-42.

21. Kudo N, Matsumori N, Taoka H, Fujiwara D, Schreiner EP, Wolff B, Yoshida M, Horinouchi S. Leptomycin B inactivates CRM1/exportin 1 by covalent modification at a cysteine residue in the central conserved region. Proc Natl Acad Sci U S A. 1999; 96:9112-9117.

22. Komiyama K, Okada K, Tomisaka S, Umezawa I, Hamamoto T, Beppu T. Antitumor activity of leptomycin B. J Antibiot (Tokyo). 1985; 38:427-429.

23. Leo AJ. Calculating log Poct from structures. Chem Rev. 1993; 93:1281-1306.

24. De Clercq E. Antiviral agents active against influenza A viruses. Nat Rev Drug Discov. 2006; 5:1015-1025.

25. Martin K, Helenius A. Nuclear transport of influenza virus ribonucleoproteins: The viral matrix protein (M1) promotes export and inhibits import. Cell. 1991; 67:117-130.

26. Elton D, Simpson-Holley M, Archer K, Medcalf L, Hallam $\mathrm{R}$, McCauley J, Digard P. Interaction of the influenza virus nucleoprotein with the cellular CRM1-mediated nuclear export pathway. J Virol. 2001; 75:408-419.

27. Lengyel J, Strain AK, Perkins KD, Rice SA. ICP27dependent resistance of herpes simplex virus type 1 to leptomycin B is associated with enhanced nuclear localization of ICP4 and ICP0. Virology. 2006; 352:368-379.

(Received November 2, 2010; Accepted November 12, 2010) 